\title{
O BRASIL E A COOPERAÇÃO JURÍDICA INTERNACIONAL COM A CORTE INTERAMERICANA DE DIREITOS HUMANOS
}

\author{
MARIA CAROLINA FLORENTINO LASCALA ${ }^{1}$ \\ RIVA SOBRADO DE FREITAS ${ }^{2}$
}

\begin{abstract}
RESUMO: A proposta é de análise da legitimidade de jurisdição da Corte Interamericana de Direitos Humanos, considerando a sua expressa aceitação pelo Estado brasileiro em 1998. A título introdutório, será visto o novo conceito de soberania que se formou com a afirmação dos direitos humanos na comunidade internacional após as grandes guerras mundiais, o que propiciou a criação de organizações internacionais protetoras desses direitos. No Brasil, a reestruturação do ordenamento jurídico nacional a partir da Constituição cidadã foi o marco histórico que enfatizou, como nunca, a importância dos direitos fundamentais. Após, será iniciado o estudo da implementação das sentenças da Corte Interamericana proferidas em desfavor do Estado brasileiro, notadamente a mais recente das decisões, no Caso da Guerrilha do Araguaia. Será possível concluir que todo o poder imperativo do sistema interamericano advém do respeito a ele dado pelos Estados-partes. Todos os esforços para a sua criação e manutenção foram e são em prol da dignidade humana e, portanto, a cooperação jurídica dos Estados com a Corte Interamericana é extremamente relevante para lhe dar efetividade e também para fortalecer este mecanismo de proteção dos direitos humanos, o que significa, dentre outras medidas, dar cumprimento às sentenças da sua Corte.

PALAVRAS-CHAVE: Corte Interamericana de Direitos Humanos; Sentença Internacional; Cooperação Jurídica Internacional.
\end{abstract}

ABSTRACT: This paper examines the legitimacy of the jurisdiction of the InterAmerican Court of Human Rights, considering its express agreement by Brazil in 1998. Firstly, we will see the new concept of sovereignty which was formed with the affirmation of human rights in the international community after the world wars, which allowed the creation of international organizations protecting

Artigo recebido em 23.07.2011. Pareceres emitidos em 02.08.2011 e 28.09.2011.

Artigo aceito para publicação em 08.01.2012.

${ }_{1}^{1}$ Mestre em Direito Público pela Universidade Estadual Paulista - UNESP, Especialista em Direito Constitucional pelo Instituto Brasiliense de Direito Público - IDP e em Direito Processual pela Universidade do Sul de Santa Catarina - UNISUL, Graduada pela Faculdade de Direito da Universidade de São Paulo - USP, Advogada da União. carollascala@hotmail.com

${ }^{2}$ Professora Assistente Doutora de Direito Constitucional e Direitos Humanos da Universidade Estadual Paulista "Júlio de Mesquita Filho" - UNESP, Franca-SP, Mestre e Doutora pela Pontifícia Universidade Católica - PUC/SP, Pós-Doutora pela Universidade de Coimbra - Portugal. rivafreit@ig.com.br 
these rights. In Brazil, the restructuring of national law from the Constitution of 1988 was the milestone which emphasized the importance of fundamental rights as never before. After, will be studied the implementation of judgments of the Inter-American Court handed down against the Brazilian State, especially the most recent decision in the Case Gomes Lund. It will be possible to conclude that all inter-American system power comes from respect given to it by states parties. All efforts to its creation and maintenance were and are in favor of human dignity. Therefore international judicial cooperation is extremely important to its effectiveness and also to give strength to this mechanism of protection of human rights, which means comply with the judgments of its court among other measures. KEYWORDS: Inter-American Court of Human Rights; International Sentence; International Judicial Cooperation.

SUMÁRIO: Introdução; 1 A Legitimidade de Jurisdição da Corte Interamericana de Direitos Humanos; 1.1 O Sistema Interamericano de Proteção dos Direitos Humanos; 1.2 A Comissão Interamericana; 1.3 A Corte Interamericana e o Brasil; 1.4 A Sentença Internacional da Corte Interamericana; 1.5 A Execução das Sentenças da Corte Interamericana; 2 O Caso Gomes Lund vs. Brasil; 2.1 Sobre a ADPF no 153/DF; 2.2 O Desfecho do Caso Gomes Lund pela Corte Interamericana; 2.3 A Cooperação Jurídica Internacional com a Corte Interamericana; Conclusão; Referências.

SUMMARY: Introduction; 1 The Jurisdiction's Legitimacy of the Inter-American Court of Human Rights; 1.1 The Inter-American Human Rights Protection; 1.2 The Inter-American Commission; 1.3 The Inter-American Court and Brazil; 1.4 The International Decision by Inter-American Court; 1.5 The Execution of Judgments of the Court; 2 The Case Gomes Lund vs. Brazil; 2.1 ADPF $n^{\circ}$ 153/DF; 2.2 The Decision on the Case Gomes Lund; 2.3 International Legal Cooperation with the Inter-American Court; Conclusion; References.

\section{INTRODUÇÃO}

A nova ordem mundial formada após a segunda grande guerra foi propulsora da criação de cortes internacionais com jurisdição para as questões de violações de direitos humanos. Nesse contexto, a criação da Corte de San José da Costa Rica foi um relevante mecanismo de proteção dos direitos humanos nos Estados do continente Americano.

O Brasil, por sua vez, com a Constituição Brasileira de 1988 declarou a prevalência dos direitos humanos como princípio orientador das suas relações internacionais. Posteriormente, em 1998, aderiu expressamente à jurisdição da Corte Interamericana de San José.

Por conta disso, em 2006, o Estado brasileiro recebeu sua primeira condenação nesta Corte ${ }^{3}$, o que incentivou os estudos sobre as formas de

\footnotetext{
${ }^{3}$ A primeira condenação do Brasil pela Corte Interamericana de San José foi no Caso Ximenes Lopes: em 1999, chegou uma petição perante a Comissão Interamericana de Direitos Humanos, alegando culpa do Estado brasileiro pelas atrocidades cometidas contra Ximenes Lopes que culminaram com sua morte dentro de uma clínica psiquiátrica em Sobral, no Estado do Ceará, na qual ele estava internado para tratamento de saúde. Após longa análise do caso ( $\left.n^{\circ} 12.237\right)$, verificou-se que Ximenes Lopes fora vítima de maus tratos e tortura que o levaram à morte dentro de uma clínica que prestava serviços públicos pelo Sistema Único de Saúde - SUS. Somada a essa barbárie, foi constatada a lentidão da Justiça Brasileira no desfecho dos
} 
implementação das sentenças internacionais em território nacional. Após, houve outras duas condenações do Brasil pela Corte Interamericana no ano de $2009^{4}$.

O Caso Gomes Lund foi o quinto caso brasileiro julgado pela Corte Interamericana e a mais recente condenação proferida em desfavor do nosso país. Também conhecido como o Caso da Guerrilha do Araguaia, possibilitou que aquele tribunal internacional analisasse a Lei de Anistia Brasileira (Lei $n^{\circ} 6.683 / 79$ ), concluindo pela sua incompatibilidade com os preceitos da Convenção Americana de Direitos Humanos.

Paralelamente e pouco antes desta sentença internacional, o Supremo Tribunal Federal também analisou a Lei de Anistia Brasileira e proferiu decisão em sede de controle concentrado, precisamente em Arguição de Descumprimento de Preceito Fundamental - ADPF, em sentido inverso ao da Corte Interamericana, ou seja, afirmando a constitucionalidade da Lei de Anistia.

Diante dessas decisões aparentemente conflitantes, o ordenamento jurídico brasileiro necessita alcançar o equilíbrio e posicionar-se sobre a implementação das sentenças internacionais, principalmente em razão da prevalência dos direitos humanos.

Esta é apenas uma das muitas problemáticas a serem vividas no Brasil em razão do entrelaçamento das ordens jurídicas interna e internacional que deverá ser solvida de forma justa e adequada à Constituição. Aliás, o inter-relacionamento entre ordenamentos jurídicos distintos está em crescente expansão e é precisamente aí que se encontram os grandes desafios do novo direito constitucional ${ }^{5}$.

\section{A LEGITIMIDADE DE JURISDIÇÃO DA CORTE INTERAMERICANA} DE DIREITOS HUMANOS

A Constituição da República Federativa do Brasil de 1988, assim como outras constituições de Estado mais modernas, dispõe logo em seu primeiro artigo que a soberania é um dos fundamentos do Estado Democrático de Direito e também afirma que "todo o poder emana do povo".

processos civil e criminal que, após muitos anos do ocorrido, ainda não havia sido concluídos. Assim, a Comissão apresentou o caso para julgamento pela Corte em outubro de 2002 e o Brasil acabou sendo condenado por violação de direitos humanos. Esta sentença impôs ao Brasil a obrigação de pagar uma indenização aos familiares da vítima, além de condená-lo às medidas de não repetição, realizando programas de capacitação para os profissionais de atendimento psiquiátrico do SUS, dentre outras obrigações. Caso Ximenes Lopes vs. Brasil. Sentença de 4 de julho de 2006. Disponível em: <http://www.corteidh.or.cr/docs/casos/articulos/ Seriec_149_esp.pdf>. Acesso em: jun. 2011.

4 No Caso Escher y Otros vs. Brasil. Sentença 06 de julho de 2009. Disponível em: <http://www.corteidh.or.cr/docs/casos/articulos/seriec_200_esp1.pdf>. Acesso em: jul. 2011. Também no Caso Garibaldi vs. Brasil. Sentença de 23 de setembro de 2009. Disponível em: <http://www.corteidh.or.cr/docs/casos/articulos/seriec_203_esp.pdf>. Acesso em: jul. 2011.

${ }^{5}$ BARROSO, Luís Roberto. O Direito Constitucional e a Efetividade de suas Normas - Limites e Possibilidades da Constituição Brasileira. 7. ed., Rio de Janeiro: Renovar, 2003, p. 129. 
Esta Carta demarcou, no âmbito jurídico, o processo de redemocratização do Estado brasileiro ao consolidar a ruptura com o regime autoritário militar, instalado em 1964, e ao consagrar os direitos e garantias fundamentais. Nas palavras de Ulysses Guimarães, Presidente da Assembleia Nacional Constituinte, ficou conhecida como a "Constituição Cidadã".

A partir dela, os direitos humanos ganharam relevo extraordinário, como jamais haviam tido anteriormente no Brasil. Esta Constituição reconheceu ainda que o princípio da dignidade humana confere sentido a todo o ordenamento jurídico, sendo seu ponto de partida e seu ponto de chegada. Foi por isso que veio expresso como fundamento da República (art. $1^{\circ}$, inciso III), acompanhando todo o movimento constitucionalista Pós-Segunda Guerra, que o consagrou como um superprincípio ${ }^{6}$.

Ante esta sistemática normativa constitucional, foi possível a ratificação de instrumentos internacionais de proteção dos direitos humanos pelo Estado brasileiro, como a Convenção Americana de Direitos Humanos, conhecida como "Pacto de San José da Costa Rica", que teve sua adesão em 1992.

Estes tratados internacionais protegem especialmente os direitos das pessoas sem preocupação com as prerrogativas dos Estados. Enquanto o sistema global, formado pela Organização das Nações Unidas - ONU, enfoca a igualdade dos povos e das nações, os sistemas regionalizados, como a Organização dos Estados Americanos - OEA, trazem particularidades próprias em busca de justiça local.

Ressalta-se ainda que a proteção internacional dos direitos humanos é complementar e subsidiária, com o principal propósito de suprir lacunas, pois já cabe ao sistema jurídico-normativo nacional a tarefa de promover esta proteção no plano interno.

Devido a este caráter subsidiário dos mecanismos de proteção internacional dos direitos humanos é que surgiu o princípio do esgotamento dos recursos internos ${ }^{7}$, sendo até mesmo uma forma de respeito à soberania dos Estados e tolerância à capacidade de se autotutelar nessas questões.

O princípio do esgotamento dos recursos internos é constantemente alegado no contencioso internacional, perante as organizações internacionais, e por elas acolhido quando provado o engajamento estatal para a solução do litígio.

No entanto, existindo realmente falha no sistema interno de proteção dos direitos humanos, poderá haver a atuação dessas organizações em prol da prevalência desses direitos, seja por recomendações (como as dadas pela

\footnotetext{
${ }^{6}$ PIOVESAN, Flávia. Direitos Humanos e o Direito Constitucional Internacional. 7. ed., São Paulo: Saraiva, 2006, p. 26.

${ }^{7}$ CANÇADO TRINDADE, Antônio Augusto. O Esgotamento dos Recursos Internos no Direito Internacional. Brasília: Editora UnB, 1984.
} 
Comissão Interamericana de Direitos Humanos) ou mesmo por sentenças condenatórias (como as da Corte Interamericana), impondo obrigações internacionais aos Estados.

\subsection{O Sistema Interamericano de Proteção dos Direitos Humanos}

Além do sistema global de proteção dos direitos humanos (ONU), foram criados os sistemas regionalizados, como o europeu, o africano e 0 americano, os quais coexistem e se completam.

O sistema interamericano tem como principal instrumento a Convenção Americana de Direitos Humanos, também conhecida como "Pacto de San José da Costa Rica", assinado em 1969 e tendo entrado em vigor em 1978, quando recebeu número suficiente de adesão dos Estados membros da OEA $^{8}$.

Pela Convenção, os Estados-partes reconhecem que os direitos essenciais do homem não derivam do fato de ser ele nacional de determinado Estado, mas sim do fato de ter como fundamento os atributos da pessoa humana, razão pela qual se justifica a proteção internacional complementar a que os Estados já oferecem por seu direito interno.

Dispõe o art. $1^{\circ}$ da Convenção que os Estados-partes comprometem-se a respeitar os direitos e liberdades nela reconhecidos e a garantir seu livre e pleno exercício a toda pessoa que esteja sujeita à sua jurisdição, sem discriminação alguma.

Quanto aos direitos que enuncia, é extensa a lista de direitos civis e políticos. No entanto, não foi feito o mesmo com os direitos sociais, culturais e econômicos, pois determinou apenas de forma genérica, em seu artigo 26, que os Estados alcancem progressivamente a plena realização destes últimos.

Foi por isso que, em 1988, foi aprovado o Protocolo de San Salvador, adicional à Convenção, que finalmente enunciou vários direitos sociais, culturais e econômicos, como o direito à saúde e à educação.

O sistema interamericano, assim como o europeu, confere ao indivíduo personalidade jurídica internacional, isto é, o ser humano passou a ser sujeito de direito internacional, capaz de possuir e exigir direitos e obrigações de cunho internacional. Isso porque estes sistemas introduziram o direito de petição a toda pessoa física que, sentindo-se lesada em algum direito humano, pode requerer a responsabilização do Estado infrator.

O reconhecimento de que os seres humanos têm direitos no âmbito internacional implica a noção de que a negação desses mesmos direitos impõe, como resposta, a responsabilização internacional do Estado violador.

Com efeito, se, no exercício de sua soberania, os Estados aceitam as obrigações jurídicas decorrentes dos tratados de direitos humanos, passam

8 ORGANIZAÇÃO DOS ESTADOS AMERICANOS. Disponível em: <http://www.oas.org>. Acesso em: jun. 2011. 
então a se submeter à autoridade das instituições internacionais, no que se refere à tutela e fiscalização desses direitos em seu território .

A fim de conferir efetividade ao sistema, a Convenção Americana estabeleceu a Comissão Interamericana de Direitos Humanos e a Corte Interamericana como mecanismos de controle das obrigações internacionais assumidas pelos Estados.

\subsection{A Comissão Interamericana}

Esta Comissão é sediada em Washington, nos Estados Unidos - EUA, com o papel de estimular os povos da América a tomar consciência dos direitos humanos, fazer recomendações aos governos, preparar estudos e relatórios, convidar os países a dar informações sobre a implementação de políticas públicas e servir à OEA como órgão consultivo.

Sua competência alcança todos os Estados-partes da Convenção Americana em relação aos direitos nela consagrados, além de alcançar todos os Estados membros da OEA, em relação aos direitos consagrados na Declaração Americana de 1948. Quanto à sua composição, é integrada por sete autoridades em direitos humanos, de qualquer Estado da OEA, eleitos pela Assembleia Geral, com mandato de quatro anos, podendo ser reeleitos uma vez.

A Comissão é também competente para examinar as comunicações encaminhadas por indivíduos ou entidade não governamental, contendo denúncia de violação de direito consagrado pelo Pacto de San José, por Estado que dele seja signatário (art. 44 e 41 da Convenção).

Pode-se dizer, então, que a Comissão funciona como um fiscal das atividades dos Estados americanos. Ela recebe as denúncias de pessoas físicas, organizações não governamentais, pessoas jurídicas, etc., e analisa os seus requisitos de admissibilidade. Entendendo por receber a denúncia, entra em contato com o Estado acusado e tenta solucionar o problema, pedindo informações a ele sobre o caso e fazendo recomendações e sugestões de como resolver o conflito.

O Brasil tem vários casos em trâmite na Comissão Interamericana e também casos já concluídos, como o Caso Maria da Penha ( $n^{\circ} 12.051$, que culminou com a edição da Lei $n^{\circ} 11.340 / 06$, contra a violência doméstica), o Caso dos Índios Yanomamis ( $n^{\circ}$ 7.615), o Caso da Penitenciária do Carandiru ( $n^{\circ}$ 11.291), o Caso do Massacre de Eldorado dos Carajás ( $\left.n^{\circ} 11.820\right)$, o Caso Hélio Bicudo ( $\left.n^{\circ} 12.397\right)$, etc ${ }^{10}$.

Porém, quando o caso não tem solução no âmbito da Comissão, ela tem legitimidade ativa para levá-lo a julgamento pela Corte Interamericana de Direitos Humanos, como será visto adiante.

${ }^{9}$ PIOVESAN, Op. Cit., p. 9

${ }^{10}$ Comissão Interamericana de Direitos Humanos. Disponível em: <http://uww.cidh.org/comissao.htm>. Acesso em: jun. 2011. 


\subsection{A Corte Interamericana e o Brasil}

A Corte Interamericana de Direitos Humanos é o órgão da OEA dotado de competência jurisdicional. Com sede em São José da Costa Rica, é formada por sete juízes indicados pelos Estados membros da OEA.

Sua competência contenciosa deriva de declaração específica do Estado reconhecendo-a, o que foi feito por quase todos os signatários da Convenção. O Brasil reconheceu a competência jurisdicional da Corte mediante o Decreto Legislativo $n^{\circ} 89$, de 3 de dezembro de 1998, aceitando se submeter ao seu julgamento para os casos ocorridos a partir de então (ex nunc).

Conforme disposição da Convenção, a Corte possui competência consultiva e contenciosa. Uma envolve o poder de adjudicar disputas relativas à denúncia de que um Estado-parte violou a Convenção (jurisdição contenciosa) e a outra é a de interpretar a Convenção Americana e determinados tratados de direitos humanos (jurisdição consultiva). No plano consultivo, qualquer Estado membro da OEA, parte ou não da Convenção, pode solicitar parecer ${ }^{11}$.

No plano contencioso, a competência é limitada aos Estados-partes da Convenção que, além disso, reconheçam tal jurisdição expressamente.

Como dito, a competência da Corte é subsidiária e complementar à dos Estados-partes, significando que somente será acionada se houver falha no sistema interno (nacional) de proteção do direitos humanos. A respeito da competência contenciosa da Corte, afirma Antônio Augusto Cançado Trindade:

"Os Tribunais internacionais de direitos humanos existentes - as Cortes Europeia e Interamericana de Direitos Humanos - não substituem os Tribunais internos, e tampouco operam como tribunais de recursos ou de cassação de decisões dos Tribunais internos. Não obstante, os atos dos Estados podem vir a ser objeto de exame por parte dos órgãos de supervisão internacional, quando se trata de verificar a sua conformidade com as obrigações internacionais dos Estados em matéria de direitos humanos"12.

A decisão da Corte tem força jurídica vinculante e obrigatória, cabendo ao Estado seu imediato cumprimento. A Corte Interamericana, portanto, jurisdicionalizou a proteção dos direitos humanos em âmbito internacional, isto é, fora dos limites de soberania de cada Estado.

\footnotetext{
${ }^{11}$ Por exemplo, os Estados Unidos da América não ratificaram o Pacto de San José e o Canadá nem ao menos é signatário deste tratado. Disponível em: <http://www.cidh.org/Basicos/Portugues/ d.Convencao_Americana_Ratif..htm>. Acesso em jul. 2011.

${ }^{12}$ CANÇADO TRINDADE, Antonio Augusto. A Interação entre o Direito Internacional e o Direito Interno na Proteção dos Direitos Humanos. Arquivos do Ministério da Justiça, Brasília, v. 46, no 182, jul./dez., 1993, p. 33.
} 
Quando os Estados reconheceram a jurisdição da Corte internacional, romperam com a clássica definição de soberania e adotaram a sua mais nova concepção, que é a de elemento de legitimidade do poder.

Conclui-se, então, ser legítimo que em nome da proteção dos direitos humanos o Estado se submeta à jurisdição de uma Corte internacional da qual ratificou seu tratado de criação, sem que isso signifique o enfraquecimento de sua soberania. Pelo contrário, o Estado está fortalecendo sua democracia e promovendo os direitos fundamentais elencados na sua Constituição.

Outro dado relevante a ser observado é o de que a jurisdicionalização internacional dos direitos humanos não precisa aspirar à universalidade para legitimar-se. Não é pelo fato de apenas alguns países aceitarem a jurisdição da Corte Interamericana que a validade de suas sentenças esteja comprometida.

A atuação da Corte tem fundamento na teoria da responsabilidade internacional do Estado e independe de reciprocidade, porquanto baseada no tratado que ratificou a sua criação.

Ciente de todo este contexto, o Brasil ratificou a jurisdição da Corte Interamericana em 1998, aceitando expressamente se sujeitar às suas decisões para os casos futuros (ou seja, para os casos ocorridos a partir desta data).

Até o presente momento, o Brasil já teve cinco casos contra ele julgados pela Corte Interamericana, sendo que obteve quatro condenações.

A legitimidade ativa para atuar na Corte é da Comissão Interamericana, como já visto, mas também de outros Estados-partes (art. 61 da Convenção). A legitimidade passiva, por sua vez, é sempre de um Estado-parte que tenha aceitado expressamente a jurisdição da Corte, o que, aliás, está prevista na Convenção Americana como cláusula facultativa.

A defesa técnica do Brasil perante esta Corte é feita pela AdvocaciaGeral da União (art. 131, da Constituição Federal), instituição essencial à justiça, prevista constitucionalmente com competência para representar a União judicial e extrajudicialmente ${ }^{13}$.

Da análise das condenações do Brasil na Corte Interamericana, pode-se notar que elas refletem os principais problemas relacionados às violações de direitos humanos em nosso país. A primeira condenação, no Caso Ximenes Lopes, avaliou a questão da saúde pública no Brasil, que não há como negar ser extremamente deficitária, sendo certo que o SUS não consegue prestar um serviço eficiente, apesar de ter sido idealizado como um modelo de sistema para a social democracia.

Em outras duas condenações, Caso Arley José Escher e Caso Sétimo Garibaldi, foi possível discutir os conflitos agrários do nosso Estado e a

\footnotetext{
${ }^{13}$ Compete à União manter relações com Estados estrangeiros e participar de organizações internacionais (art. 21, inciso I, Constituição Federal).
} 
questão da necessidade de reforma agrária, o que, aliás, é uma dívida social de séculos.

Enfim, na última condenação, a Corte analisou os crimes da ditadura militar, que foram uma mancha na história brasileira, portanto, está na hora de o Estado reconhecer seus erros e buscar reparar os danos causados.

Deste modo, no exercício da sua função jurisdicional, a Corte, de fato, julga o Estado acusado e profere sentença que, sendo condenatória, declara a responsabilidade internacional do Estado pela violação de direitos humanos.

\subsection{A Sentença Internacional da Corte Interamericana}

A decisão condenatória proferida pela Corte Interamericana deve ser classificada como sentença internacional. Ela não se confunde com a sentença estrangeira, que é aquela que necessita de homologação pelo Superior Tribunal de Justiça - STJ para ser executada no Brasil (art. 105, I, i, Constituição Federal). É que a sentença estrangeira é proferida por outro Estado soberano e, por isso, o STJ verifica se ela não ofende a soberania nacional e a ordem pública.

Já a sentença internacional, como a proferida pela Corte Interamericana, advém de um organismo internacional do qual o Estado em que ela vai ser executada é sempre parte do tratado que o criou e aceitou espontaneamente sua jurisdição de forma expressa.

Sendo assim, não há que se falar em necessidade de homologação da sentença da Corte Interamericana para a sua execução no Brasil ${ }^{14}$.

Ao aderir à jurisdição desta Corte, o Estado transfere parte do seu poder de império para este ente internacional em prol de valores maiores e constitucionais, como a prevalência dos direitos humanos.

Este é o caso da sentença proferida pela Corte Interamericana, da qual o Brasil faz parte e se sujeitou em favor da dignidade humana, devendo adaptar seu ordenamento interno para recepcionar esta decisão internacional autoexecutável dentro de suas fronteiras territoriais.

Dispõe a Convenção Americana, em seu artigo 63.1, que:

"Quando decidir que houve violação de um direito ou liberdade protegidos nesta Convenção, a Corte determinará que se assegure ao prejudicado o gozo do seu direito ou liberdade violados. Determinará também, se isso for procedente, que sejam reparadas as consequências da medida ou situação que haja configurado a violação desses direitos, bem como o pagamento de indenização justa à parte lesada."

A partir da declaração de responsabilidade internacional do Estado, a sentença internacional impõe obrigações ao condenado na tentativa de

${ }^{14}$ PETIOT, Patrick. A Responsabilidade Internacional do Estado Brasileiro por Violação de Direitos Humanos: o pagamento de reparações. Dissertação de Mestrado, Faculdade de Direito da Universidade de Brasília - UnB, Brasília, 2005, p. 169.

DiREITOS FundaMentaIS E JUSTIÇA - ANo 6, N' 18, P. 97-119, JAN./MAR. 2012 
reparar as violações cometidas. Estas reparações impostas constituem obrigações internacionais cujo descumprimento pode gerar novas sanções.

Cabe, então, ao Estado condenado acatar a decisão internacional e internalizar os seus mandamentos, cumprindo com suas obrigações e cooperando com a Corte Interamericana, porquanto o respeito às suas decisões também fortalece e legitima o sistema interamericano.

No caso do Brasil especificamente, o artigo $7^{\circ}$ do Ato das Disposições Constitucionais Transitórias - ADCT (que possui status constitucional) dispõe que nosso Estado propugnará pela criação de um tribunal internacional de direitos humanos. Logo, faz todo sentido que ele respeite a Corte Interamericana, reconheça sua jurisdição e cumpra com suas sentenças, cooperando com este tribunal internacional.

\subsection{A Execução das Sentenças da Corte Interamericana}

Uma vez proferida a sentença condenatória pela Corte Interamericana, ela deverá ser executada no Estado-parte. O art. 68 da Convenção Americana dispõe que cada Estado deve cumprir a decisão condenatória de acordo com seu ordenamento jurídico interno. Ou seja, há liberdade quanto à forma de execução das sentenças, conforme a normatividade interna. Isto é, desde que cumpra em um prazo razoável, porquanto o descumprimento da sentença implica nova violação das obrigações internacionais.

Em verdade, as sentenças têm por praxe fixar indenizações pecuniárias, obrigações de fazer (como dar publicidade à sentença internacional, etc.) e também medidas de não repetição, consistentes em obrigações impostas ao Estado condenado no sentido de se evitar futuras violações de direitos humanos como a ocorrida.

O art. 68.2 da Convenção prevê que as indenizações fixadas na sentença podem ser pagas nos mesmos moldes que o Estado faz quando é condenado internamente, ou seja, podem ser pagas assim como o são as dívidas fixadas pelas sentenças condenatórias nacionais.

Foi por causa deste dispositivo convencional que os primeiros estudiosos do tema a respeito da implementação das sentenças internacionais da Corte Interamericana no Brasil afirmaram que as indenizações fixadas podiam ser pagas pelo sistema de precatórios (art. 100, Constituição Federal) que é o modo pelo qual o Estado paga suas dívidas judiciais.

De fato, o sistema de pagamentos por precatórios das dívidas da Fazenda Pública enfatiza a isonomia entre os credores e o princípio da impessoalidade, impedindo qualquer espécie de favorecimento, seja por razões políticas, seja por razões pessoais ${ }^{15}$.

André de Carvalho Ramos ${ }^{16}$, ao interpretar o art. 68.2 da Convenção, concluiu pela via do processo de execução contra a Fazenda Pública, nos

${ }^{15}$ MORAES, Alexandre de. Direito Constitucional. 15. ed., São Paulo: Editora Atlas, 2004, p. 509.

${ }^{16}$ RAMOS, André de Carvalho. Direitos Humanos em Juízo. São Paulo: Max Limonad, 2001, p. 499. 
termos do artigo 100 da Constituição Federal e dos artigos 730 e 731 do Código de Processo Civil. Este foi também o entendimento de Patrick Petiot ${ }^{17}$ e Janice Cláudia Freire Sant' na ${ }^{18}$.

Sobre o sistema de pagamentos por precatórios, elucidou Pontes de Miranda: "Não digamos que seja perfeito. Reconheçamos-Ihe a juridicidade e a eticidade dos seus propósitos"19.

Porém, apesar de originalmente o uso do precatório ter sido elevado à dignidade magna para moralizar os pagamentos feitos pelo Estado, em verdade, tornou-se um pesadelo para quem tem créditos a receber do erário. É que à morosidade dos precatórios e da justiça brasileira se somam os entraves burocráticos para a obtenção do seu efetivo pagamento.

No caso das indenizações fixadas pela Corte Interamericana de Direitos Humanos, a demora no pagamento poderia significar o descumprimento da sentença internacional, porque, geralmente, há um prazo para que suas ordens sejam cumpridas, sendo praxe não ultrapassar 12 meses e, como sabido, os precatórios não são pagos neste período.

Ocorre que, após a primeira decisão condenatória no Caso Ximenes Lopes, a União passou a prever rubrica orçamentária com destinação de verbas para pagamento das indenizações impostas por Corte internacional, facilitando o cumprimento deste capítulo da sentença internacional e pondo fim à discussão.

Em artigo recente, André de Carvalho Ramos menciona haver previsão de dotação específica para pagamento de indenização a vítimas de violações de direitos humanos na lei orçamentária anual de 2009 e 2010, concluindo estar superada esta questão dos pagamentos por precatório ou mesmo por lei específica, como já ocorreu ${ }^{20}$.

Por fim, as indenizações estabelecidas pelas sentenças da Corte Interamericana mostraram-se a parte mais simples de ser cumprida pelo Estado condenado, pois resumem toda a complexa discussão dos direitos humanos em pagamento pecuniário.

No entanto, a indenização nunca é suficiente por si só. Em casos de violações de direitos humanos, como do direito à vida e à integridade física, a volta ao status quo ante é muito difícil (e, às vezes, impossível). Assim, geralmente, são fixadas outras medidas de reparação, dentre elas, inclusive, medidas com o fim de que o Estado evite futuras violações.

\footnotetext{
${ }^{17}$ PETIOT, Op. Cit, p. 169.

${ }^{18}$ SANT'ANA, Janice Cláudia Freire. O Brasil e a Execução de Sentença da Corte Interamericana de Direitos Humanos. In: ANNONI, Danielle (org.). Os Novos Conceitos do Novo Direito Internacional: Cidadania, Democracia e Direitos Humanos. Rio de Janeiro: América Jurídica, 2002, p. 267.

${ }^{19}$ Apud PETIOT, Patrick. Op. Cit., p. 132.

${ }^{20}$ RAMOS, André de Carvalho. Crimes da Ditadura Militar: a ADPF 153 e a Corte Interamericana de Direitos Humanos. In: GOMES, Luiz Flávio; MAZZUOLI, Valerio de Oliveira (org.). Crimes da Ditadura Militar: uma análise à luz da jurisprudência atual da Corte Interamericana de Direitos Humanos: Argentina, Brasil, Chile, Uruguai. São Paulo: Editora Revista dos Tribunais, 2011, p. 220.
} 
Pode-se dizer que as medidas de não repetição são imposições internacionais com o fim de que o Estado adote políticas públicas tendentes à concretização dos direitos humanos.

Veja-se que a garantia de não repetição e a obrigação de investigar e sancionar os responsáveis são obrigações impostas pela Corte Interamericana aos poderes executivo, legislativo e judiciário do Estado condenado e mesmo ao Ministério Público no Brasil, a quem cabe a titularidade da ação penal pública.

Da análise das resoluções de supervisão de sentença emitidas pela Corte Interamericana, verifica-se que os países que aceitaram sua jurisdição vêm oferecendo resistência ao cumprimento das medidas de não repetição ${ }^{21}$.

As obrigações não pecuniárias têm sido menos cumpridas pelos Estados condenados, principalmente, por não existir um consenso sobre qual o procedimento a ser adotado, por exemplo, quando a Corte determina a implementação de determinadas políticas públicas visando à efetivação de direitos humanos (ex: políticas públicas na área da saúde, políticas de reforma agrária, políticas de implementação de direitos trabalhistas, etc).

Realmente, não é fácil a tarefa da Corte Interamericana em condenar um Estado exigindo que o mesmo adote medidas legislativas, administrativas e mesmo judiciárias tendentes à realização dos direitos humanos, mas esta é a função deste mecanismo criado com a finalidade de fiscalizar e promover esses direitos no sistema interamericano.

O Brasil ainda não adotou legislação específica prevendo o modo de cumprimento das sentenças internacionais, a chamada enabling legislation, a exemplo de outros países como a Colômbia e o Peru.

Há inclusive projetos de lei tramitando no Congresso Nacional para a solução da lacuna jurídica quanto à forma de cumprimento dessas decisões ${ }^{22}$, mas que só tratam do pagamento das indenizações pelo Estado e nada mencionam sobre a implementação das demais reparações.

Qualquer um deles que seja aprovado nos termos em que está propostos, a lacuna persistirá e o Brasil continuará sem um caminho certo a percorrer nesses casos de condenações internacionais.

Considerando o disposto no artigo $2^{\circ}$ da Convenção Americana, o Brasil já deveria ter aprovado tal legislação há tempos:

\footnotetext{
${ }^{21}$ MAEOKA, Érika. O Acesso à Justiça e a Proteção dos Direitos Humanos: os desafios à exigibilidade das sentenças da Corte Interamericana. Trabalho publicado nos Anais do XVII Congresso Nacional do CONPEDI, realizado em Brasília-DF, em nov. 2008.

${ }^{22}$ Por exemplo, o Projeto de Lei $n^{\circ} 4.667 / 2004$, de autoria do então Deputado Federal José Eduardo Cardozo (PT-SP), atual Ministro da Justiça, que dispõe sobre os efeitos jurídicos das decisões dos organismos internacionais de proteção aos direitos humanos. Há também os substitutivos deste mesmo projeto, como o da Comissão de Constituição e Justiça (Relator Deputado Luiz Couto). Além de haver o Projeto de Lei do Senado Federal de n 420/2009, dentre outros.
} 
Art. $2^{\circ}$ - Dever de adotar disposições de direito interno:

Se o exercício dos direitos e liberdades mencionados no art. $1^{\circ}$ ainda não estiver garantido por disposições legislativas ou de outra natureza, os Estados-partes comprometem-se a adotar, de acordo com as suas normas constitucionais e com as disposições desta Convenção, as medidas legislativas ou de outra natureza que forem necessárias para tornar efetivos tais direitos e liberdades.

Esse dispositivo estabelece a necessidade de se criar um procedimento de execução para as sentenças internacionais, conferindo-lhe agilidade e eficiência.

Além disso, o artigo 27 da Convenção de Viena dispõe que os Estados não podem invocar disposições de direito interno para justificar o inadimplemento de obrigações oriundas de um tratado internacional.

E também, de acordo com os ensinamentos de André de Carvalho Ramos, a sentença da Corte Interamericana é uma obrigação de resultado e, por isso, não importam os meios internos adotados para o seu cumprimento:

"A obrigação internacional de cumprimento da decisão relativa à proteção de direitos humanos é em última análise uma obrigação de resultado, cabendo ao Estado infrator a escolha dos meios para o seu cumprimento",23.

Portanto, sendo a decisão internacional uma obrigação de resultado, o Estado possui liberdade para escolher os meios internos que entenda adequados para fazer cumprir o conteúdo da sentença.

Ainda que não se tenha atualmente um método perfeito de internalização das sentenças internacionais, é preciso escolher algum que encontre o equilíbrio entre o sistema jurídico interno e o internacional para o cumprimento das sentenças.

Quando a Corte Interamericana condena um Estado-parte, impondo a ele a realização de determinada política pública, é possível equiparar esta sentença a uma sentença nacional para fins de execução, ou seja, ela será cumprida dentro dos limites da proporcionalidade e da razoabilidade da condenação.

É certo que as obrigações não pecuniárias impostas aos Estados têm como objetivo a punição e a prevenção de novas violações, com a pretensão de eliminar as deficiências da rede interna de proteção dos direitos humanos.

A eficácia do sistema interamericano de proteção dos direitos humanos está diretamente vinculada ao êxito da execução dessas decisões da Corte. A Justiça internacional somente cumprirá efetivamente seu papel de promover os direitos humanos no momento em que as suas decisões forem acatadas de boa-fé e com lealdade pelos Estados-partes.

${ }^{23}$ RAMOS, Op. Cit., 2001, p. 296.

DiREITOS FundAMENTAIS E JUSTIÇA - ANo 6, N' 18, P. 97-119, JAN./MAR. 2012 
Apesar de todos os entraves, o Brasil não pode deixar de cumprir com a sentença da Corte Interamericana, pois não há dúvidas de que sua jurisdição é constitucional.

Enquanto as propostas de lei para o cumprimento das sentenças da Corte Interamericana seguem sua tramitação parlamentar, essas decisões devem ser cumpridas pelo Estado brasileiro, de forma constitucional e com respeito a todo o ordenamento pátrio, de forma motivada e coerente com a realidade orçamentária nacional.

É inegável a imprescindibilidade de legislação ordinária disciplinando o tema para não haver um campo tão rico para as interpretações e manobras jurídicas, o que, apesar de boas intenções, pode não estar atingindo o ideal de justiça.

As consequências internacionais pelo descumprimento da sentença são severas e se iniciam pela apresentação do caso na Assembleia Geral da OEA, onde serão discutidas as sanções internacionais a serem impostas.

Considerando que o Brasil busca sua afirmação internacional como um país economicamente sólido e cumpridor dos direitos humanos, deve continuar buscando a melhor forma de reparar as violações internacionais reconhecidas pela Corte Interamericana.

\section{O CASO GOMES LUND VS. BRASIL}

Também conhecido como o Caso da Guerrilha do Araguaia, teve início com a petição do CEJIL (Centro pela Justiça e o Direito Internacional) e a Human Rigths Watch/Americas, que, em 1995, denunciou à Comissão Interamericana a responsabilidade do Estado brasileiro pelo desaparecimento forçado de membros do partido comunista (PCdoB) e de camponeses da região do Araguaia que se uniram e planejavam contra o governo militar instaurado no Brasil em $1964^{24}$.

Teriam desaparecido cerca de 70 pessoas entre 1972 e 1975, que realizavam oposição à ditadura. As famílias dessas pessoas sofriam com a falta de informações e estavam em busca da verdade dos fatos ocorridos, o que a Lei de Anistia brasileira (Lei $n^{0}$ 6.683/79) impedia que fosse feito, obstando investigações criminais e mesmo o acesso a arquivos e documentos da época. Em razão de o fato não possuir solução no âmbito nacional, buscaram ajuda internacional por causa dos direitos humanos violados.

Após 13 anos de avaliação na Comissão Interamericana, esta denunciou o caso para julgamento pela Corte em 2009. É que, apesar de o Estado brasileiro ter adotado algumas medidas para amenizar o sofrimento das vítimas, como a edição da Lei no 9.140/95 - que reconheceu a morte de desaparecidos políticos na época da ditadura militar e previu o pagamento

\footnotetext{
${ }^{24}$ Caso Gomes Lund y Otros vs. Brasil. Sentença de 24 de novembro de 2010. Disponível em: $<$ http://www.corteidh.or.cr/docs/casos/articulos/seriec_219_esp.pdf>. Acesso em: jul. 2011. 
de indenizações aos familiares, faltaram investigações cíveis e criminais e principalmente desvendar a verdade dos fatos ocorridos naquele período.

Em contestação, o Estado brasileiro alegou quatro exceções preliminares, impeditivas da análise do mérito da questão pela Corte. A primeira delas foi o fato de a Corte não ter competência temporal para julgar o caso dos desaparecidos políticos do período da ditadura militar, que é anterior à data de aceitação da jurisdição da Corte pelo Brasil (1998).

Como já fora dito, a aceitação da jurisdição internacional se deu com aplicação do princípio da irretroatividade, portanto, os casos passados estariam excluídos de apreciação pela Corte.

Em sentença, proferida em novembro de 2010, a Corte afastou esta preliminar de incompetência temporal, afirmando que não estava julgando os crimes cometidos no período da ditadura militar, mas as consequências deles que perduram até a atualidade, como o sofrimento dos familiares que é presente, a falta de informações sobre o ocorrido, a falta da prestação da verdade pelo Estado, dentre outras violações de direitos humanos advindas pela manutenção da Lei de Anistia (Lei $n^{\circ} 6.683 / 79$ ) em vigor, que por si só representa um afronta aos direitos humanos. Além do mais, é farta a jurisprudência da Corte no sentido de ser competente para julgar os atos de caráter contínuo ou permanente que perduram após a aceitação da sua jurisdição internacional.

A segunda exceção preliminar alegada foi a falta de interesse processual dos representantes contra o Estado brasileiro, porque a Lei ${ }^{\circ} 9.140 / 95$ já havia indenizado as famílias dos desaparecidos políticos da ditadura militar. Também a Corte afastou tal alegação, pois se estava buscando muito mais do que indenizações pecuniárias, como a verdade dos fatos, os restos mortais, investigações criminais e punições, bem como acesso aos arquivos e documentos da época.

A falta de esgotamento dos recursos internos foi a terceira preliminar alegada pelo Brasil e consistiu em afirmar que a jurisdição nacional está analisando questão idêntica à da Corte, o que a impediria de se sobrepor à decisão nacional, dado o seu caráter suplementar. Havia em trâmite perante a justiça brasileira uma ação ordinária no Distrito Federal (nº 82.00.02468-2-5) em fase de execução, que condenara a União à apresentação dos documentos existentes sobre a ditadura militar aos familiares das vítimas. Também uma ação civil pública movida pelo Ministério Público Federal no Pará buscava a reparação pelos desaparecidos na Guerrilha do Araguaia.

No entanto, a Corte dispôs que esta defesa deveria ter sido apresentada ainda na fase de processamento perante a Comissão e que a demora na prestação jurisdicional equivale à sua não prestação, o que significa que o Brasil não conseguiu resolver este problema internamente, justificando a intervenção internacional da Corte Interamericana.

Como quarta e última exceção preliminar, o Estado brasileiro alegou a existência de uma causa superveniente que impediria a análise do mérito do 
Caso pela Corte Interamericana: o julgamento da Arguição de Descumprimento de Preceito Fundamental - ADPF n 153 pelo Supremo Tribunal Federal ${ }^{25}$, a mais alta corte brasileira, a qual teria reconhecido a constitucionalidade da Lei de Anistia, ou melhor, teria reconhecido que a Constituição de 1988 recepcionou esta Lei, sob o argumento de que se tratou de um pacto fundamental para a redemocratização do Brasil. Sendo assim, a Corte Interamericana não poderia atuar como uma quarta instância.

A esse respeito, a Corte dispôs que o objeto da sua análise era diferente daquele da ADPF brasileira. Afirmou que ela é a última autoridade para avaliar o cumprimento da Convenção Americana de direitos humanos pelos Estados signatários e que realiza um controle de convencionalidade dos atos dos Estados em relação às obrigações internacionais assumidas.

Enfatizou ainda que não há pretensão de rescindir julgados nacionais e que questões de direito interno não Ihe competem, razão pela qual não lhe afeta a decisão do STF. Mas se interessa por obrigar os Estados a cumprir com as disposições da Convenção Americana e que, nesse contexto, a Lei de Anistia deve ser avaliada.

\subsection{Sobre a ADPF $n^{\circ}$ 153/DF}

O Conselho Federal da Ordem dos Advogados do Brasil - OAB ajuizou Arguição de Descumprimento de Preceito Fundamental pedindo a declaração de não recepção do $\S 1^{\circ}$ do art. $1^{\circ}$ da Lei $n^{0} 6.683 / 79^{26}$ pela Constituição democrática de 1988. Argumentou ser notória a controvérsia constitucional acerca da aplicação da Lei de Anistia, havendo divergência de entendimentos até mesmo entre os órgãos da União. Com isso, objetivava-se a possibilidade de investigação penal de autores de crimes comuns cometidos por agentes públicos sob o manto da motivação política.

Como já fora dito, o Supremo Tribunal Federal afirmou, por maioria de votos, a recepção do mencionado dispositivo e concluiu pela constitucionalidade da Lei de Anistia. O Ministro relator do acórdão afirmou que a Lei de Anistia teria sido um acordo político para a transição pacífica à democracia e, além do mais, foi geral para alcançar tanto os militares como os opositores do governo. Ainda citando o exemplo de nossos vizinhos (Chile, Argentina e Uruguai), afirmou que a revisão da lei de anistia deve ser feita pelo Poder Legislativo e não pelo Poder Judiciário.

\footnotetext{
${ }^{25}$ Acórdão em <http://redir.stf.jus.br/paginadorpub/paginador.jsp?docTP=AC\&docID=612960>

${ }^{26}$ Lei 6.683, de 19 de dezembro de 1979: Art. $1^{\circ} \dot{E}$ concedida anistia a todos quantos, no período compreendido entre 02 de setembro de 1961 e 15 de agosto de 1979, cometeram crimes políticos ou conexo com estes, crimes eleitorais, aos que tiveram seus direitos políticos suspensos e aos servidores da Administração Direta e Indireta, de fundações vinculadas ao poder público, aos Servidores dos Poderes Legislativo e Judiciário, aos Militares e aos dirigentes e representantes sindicais, punidos com fundamento em Atos Institucionais e Complementares. $\S 1^{\circ}$ Consideram-se conexos, para efeito deste artigo, os crimes de qualquer natureza relacionados com crimes políticos ou praticados por motivação política.
} 
O Ministro Relator da ADPF, Min. Eros Grau, terminou seu voto registrando que a decisão pela improcedência da ação não excluía o repúdio a todas as modalidades de tortura, de ontem e de hoje, civis e militares, policiais e delinquentes.

No voto vencido do Ministro Ricardo Lewandowski, bem argumentou sobre o caráter permanente do crime de sequestro, enquanto a vítima estiver privada de sua liberdade ou os seus restos mortais não forem encontrados, inaplicando ainda a prescrição para estes casos. Além disso, afirmou ser inaplicável a anistia e tecnicamente errado estender o conceito penal de crimes conexos a toda e qualquer barbárie cometida em nome da ditadura.

Acompanhando o voto vencido, o Ministro Ayres Britto enfatizou que o Congresso que aprovou a Lei de Anistia não era legítimo e que a ideia de anistia não pode se estender aos crimes de lesa humanidade.

Apesar disso, os demais ministros da Suprema Corte brasileira desconsideraram por completo os direitos humanos vigentes no atual Estado democrático brasileiro e foram complacentes com as atrocidades cometidas pela ditadura militar.

\subsection{O Desfecho do Caso Gomes Lund pela Corte Interamericana}

A sentença da Corte neste caso foi proferida em 24 de novembro de 2010 e enfaticamente julgou a Lei de Anistia brasileira incompatível com a Convenção Americana de direitos humanos. Afirmou que o Estado brasileiro é responsável pelo desaparecimento forçado das pessoas que afrontaram a ditadura militar na Guerrilha do Araguaia e ainda que o Brasil descumpre com a obrigação de adequar seu ordenamento interno ao Pacto de San José, conforme artigo $2^{\circ}$ deste diploma.

Condenou o Estado brasileiro por violação dos artigos 1,2, 3, 4, 5, 7, 8, 13, 25, do Pacto de San José, ordenando o pagamento de indenizações, e impôs a obrigação de investigar os fatos ocorridos na Guerrilha do Araguaia, determinando o paradeiro das vítimas desaparecidas, além de oferecer tratamento médico aos familiares dos desaparecidos políticos, implementar um programa permanente e obrigatório sobre direitos humanos nas Forças Armadas brasileiras, dentre outras medidas reparatórias.

Da análise desta decisão, é possível destacar os tipos de reparações que costumeiramente são impostas pela Corte Interamericana: indenização pecuniária por danos morais e materiais, obrigações de fazer consistentes em reparar o dano moral (como a publicação da sentença em veículo de grande circulação nacional) e medidas de não repetição, consistentes em evitar novas violações (como a implementação de programa permanente e obrigatório sobre direitos humanos nas Forças Armadas).

A Corte Interamericana, apesar dos esforços da defesa, foi bastante categórica em afirmar que lhe compete a análise dos atos do Estado em relação à Convenção Americana, separando nitidamente a sua jurisdição da jurisdição nacional. Assim, ela realiza um controle dos atos estatais 
(dos três poderes: executivo, legislativo e judiciário) tendo como paradigma o tratado internacional por ele assinado.

Ao final, impôs obrigações que, ao serem internalizadas, significam obrigações não só ao executivo, mas também ao legislativo e ao judiciário. Exemplos: a) a obrigação de tipificar o crime de desaparecimento forçado de pessoas é medida de não repetição imposta ao Poder Legislativo; b) o dever de implementar um programa de direitos humanos nas forças armadas é medida de não repetição imposta ao Poder Executivo; c) o dever de conduzir a investigação penal dos fatos do Caso da Guerrilha do Araguaia perante a jurisdição nacional é imposto ao Poder Judiciário e também ao Ministério Público, enquanto titular da ação penal pública.

Sendo assim, resta claro que todos os poderes do Estado devem estar comprometidos com a Corte Interamericana, o que, em última análise, é estar comprometido com os direitos humanos e com a Constituição brasileira.

As formas de internalizar as determinações desta sentença devem ser discutidas pelo Estado com prioridade, dada a gravidade de uma condenação internacional.

2.3 A Cooperação Jurídica Internacional com a Corte Interamericana

Como visto, o Brasil não possui uma legislação específica que discipline o modo de cumprimento das sentenças da Corte Interamericana. A edição desta lei seria bastante relevante, principalmente por causa do excesso de burocracia no Estado brasileiro (seja na administração pública ou mesmo nos processos judiciais). Com ela, não haveria dúvidas sobre a forma de cumprir com as obrigações, nem a quem competiria coordenar e fiscalizar este cumprimento no âmbito interno.

Porém, isso não é impeditivo de se executar a sentença, tanto que o Brasil vem executando todas as outras condenações que recebeu anteriormente. Também como já visto, a sentença internacional traz uma obrigação de resultado, independendo dos meios utilizados para a sua execução, o que torna 0 Estado livre para escolher o meio mais adequado às suas possibilidades.

A execução das sentenças internacionais que condenam o Estado brasileiro à promoção dos direitos humanos e a evitar novas violações pode partir da equiparação mutatis mutandi com as sentenças nacionais que igualmente condenam o Estado (pessoa jurídica de direito público) a medidas assemelhadas.

As sentenças judiciais nacionais que impõem ao Estado a realização de uma obrigação de fazer consistente em concretização de um direito fundamental devem respeitar a discricionariedade administrativa e as funções típicas dos poderes de Estado, bem como as restrições orçamentárias. O mesmo pode ser dito em relação à sentença da Corte Interamericana.

Especificamente no Caso da Guerrilha do Araguaia, não se vislumbra conflito entre a decisão do STF na ADPF no 153/DF e a sentença da Corte Interamericana. Primeiramente, porque a decisão do STF se limitou a declarar 
que a Lei de Anistia (Lei $n^{\circ}$ 6.683/79) foi recepcionada pela Constituição de 1988. Isso não significa que a Lei de Anistia tenha status constitucional, apenas que ela era válida e produzia regularmente seus efeitos.

No entanto, após esta decisão do STF, sobreveio a decisão da Corte Interamericana e sua sentença tem status de tratado internacional de direitos humanos.

Pela análise da jurisprudência mais recente do STF, a suprema corte brasileira confere status supralegal aos tratados de direitos humanos que não forem aprovados tal como uma emenda constitucional ${ }^{27}$.

Logo, é de se concluir que a sentença internacional que prevê a incompatibilidade da Lei de Anistia com o Pacto de San José derroga os dispositivos desta lei ordinária. Ou seja, a sentença internacional é posterior e hierarquicamente superior à Lei de Anistia, devendo, portanto, prevalecer para todos os fins.

O Ministério Público terá papel fundamental para exigir o cumprimento das sentenças internacionais pelo Estado, porque é sua função constitucional a defesa da ordem jurídica, do regime democrático e dos interesses sociais e individuais indisponíveis (artigo 127 da Constituição Federal).

Os direitos humanos foram declarados formalmente para o fim de serem materializados. O cumprimento das sentenças da Corte Interamericana de Direitos Humanos é a demonstração de respeito a estes direitos, aos tratados internacionais que os declararam e à própria continuidade da democracia brasileira.

\section{CONCLUSÃO}

Após a história provar o triunfo das democracias liberais frente às ditaduras de direita e mesmo de esquerda, os Estados encontram outras dificuldades para cumprir suas responsabilidades de promessa de fornecer segurança (paz), desenvolvimento econômico e social (bem estar) ${ }^{28}$.

Portanto, a tendência mundial é fazer surgir uma nova ordem constitucional nos Estados que reconheça os novos desafios da sociedade globalizada e afaste o conceito de soberania tal como previsto na formação dos Estados modernos, que não mais atende às prioridades sociais, priorizando a dignidade humana.

Deste modo, face à proteção internacional dos direitos humanos, tornou-se legítima a intervenção na jurisdição doméstica dos Estados que desrespeitem esses direitos, sem que isso signifique ameaça à soberania nacional.

\footnotetext{
${ }^{27}$ SUPREMO TRIBUNAL FEDERAL. RE no 466.343-SP, Rel. Min. Cesar Peluso. Jul. 03.12.2008. Disponível em: <http://www.stf.jus.br/imprensa/pdf/re466343.pdf>. Acesso em: jul. 2011.

${ }^{28}$ BOBBITT, Philip. A Guerra e a Paz na História Moderna: o impacto dos grandes conflitos e da política na formulação das nações. Tradução de Cristiana Serra, Rio de Janeiro: Campus, 2003, p. 196.
} 
Em primeiro lugar, porque os organismos internacionais foram criados pelos próprios Estados engajados em causas maiores como a proteção dos direitos humanos, a busca da paz mundial, o progresso das relações econômicas, entre outras. Quando assim agem, os Estados transferem parte do exercício da soberania a estes organismos, sem renunciá-la.

Somente o Estado soberano pode aderir aos organismos internacionais e isso significa, em primeira análise, nítida manifestação do poder de se autodeterminar e da sua independência internacional, pois apenas pode transferir o exercício de um poder quem realmente o possua e sobre ele seja livre.

Com a internacionalização dos direitos humanos, muitos doutrinadores afirmam que a relativização da soberania estatal atua em benefício da efetivação desses direitos e justifica-se em prol do bem comum universal ${ }^{29}$. Flávia Piovesan ${ }^{30}$, em uma palestra proferida em 1999, explicou:

"Só há direitos humanos, globais, internacionais, universais, com soberania flexibilizada. [...]

Portanto, no que tange ao impacto do Direito Internacional dos Direitos humanos na concepção de soberania, destaco a afirmação do SecretárioGeral da ONU, quando diz que, ainda que o respeito à soberania do Estado seja uma questão central, é inegável que a antiga doutrina da soberania exclusiva e absoluta não mais se aplica. Uma das maiores exigências, diz ele, do nosso tempo, é a de repensar o conceito de soberania. Enfatizar os direitos dos indivíduos e dos povos é uma dimensão da soberania universal. [...]

Lembro-me de um livro que li há pouco do Professor Abram Chayes, da Universidade de Harvard, chamado The New Sovereignty, em que ele diz que a soberania não pode mais consistir na liberdade dos Estados de atuarem independentemente e de forma isolada à luz do seu interesse específico e próprio. A soberania hoje consiste, sim, numa cooperação internacional em prol de finalidades comuns."

Sendo assim, inegável que a jurisdição da Corte é legítima e foi aceita expressamente pelo Estado brasileiro. Consequentemente, suas sentenças são comandos imperativos com força vinculante, eficácia imediata e autoexecutável.

${ }^{29}$ O autor Rogério Taiar, analisando Norberto Bobbio (A Era dos Direitos), Fábio Konder Comparato (A Afirmação Histórica dos Direitos Humanos), Celso Lafer (A Soberania e os Direitos Humanos. In: Revista de Cultura e Política "Lua Nova", nº 35, p.137-148. São Paulo: CEDEC, 1995), dentre outros, chega à conclusão que a relativização da soberania se faz em prol dos direitos humanos. TAIAR, Rogério. Direito Internacional dos Direitos Humanos: uma discussão sobre a relativização da soberania face à efetivação da proteção internacional dos direitos humanos. Tese de Doutorado, 2009, p. 258-259.

30 PIOVESAN, Flávia. Palestra proferida no Seminário Internacional "O Tribunal Penal Internacional e a Constituição Brasileira", promovido pelo Centro de Estudos Judiciários do Conselho da Justiça Federal, no dia $1^{\circ}$ de outubro de 1999, no auditório do Superior Tribunal de Justiça, em Brasília - DF. Revista CEJ, Brasília, nº 11, p. 65-74, maio/ago., 2000. p. 71-72. 
Além de possuir status de norma constitucional, dada a sua natureza de tratado de direitos humanos ${ }^{31}$.

Ademais, é certo que nosso país já realizou diversos atos concretos que sinalizam o reconhecimento de sua legitimidade: o Brasil apresenta defesa escrita e oral nas audiências da Corte; designa representantes do governo para atuarem como autoridades responsáveis pelo Estado nessas audiências; há projetos de lei da Câmara e do Senado Federal tramitando no Congresso Nacional sobre o modo de cumprimento das suas sentenças; há pareceres jurídicos favoráveis ao cumprimento de suas decisões pela Advocacia-Geral da União, notadamente nas consultorias jurídicas dos Ministérios da Justiça, das Relações Exteriores e da Secretaria Especial de Direitos Humanos; há decisões judiciais em todas as instâncias, inclusive no STF, reconhecendo o status constitucional dos tratados internacionais de direitos humanos, como o Pacto de San José da Costa Rica ${ }^{32}$; a Secretaria Especial de Direitos Humanos, órgão equiparado a um Ministério do Poder Executivo Federal, possui competência para conduzir o cumprimento das sentenças da Corte Interamericana e o vem fazendo desde a sentença no Caso Ximenes Lopes, além de prestar informações periódicas à Corte sobre as medidas adotadas pelo Estado brasileiro.

Diante disso, não restam dúvidas sobre a obrigatoriedade de cooperação internacional no Caso da Guerrilha do Araguaia, devendo a Lei de Anistia brasileira ser desconsiderada, principalmente para fins de se levar adiante as investigações penais que conduzirão à verdade sobre o ocorrido.

No caso em tela, aplica-se bem o pensamento de Hannah Arendt $^{33}$, sobre a necessidade de reconstrução dos direitos humanos logo após as barbáries cometidas, começando por reconhecer que o ser humano tem direito a ter direitos. O Brasil urge em reconhecer que não basta a declaração formal dos direitos fundamentais, é preciso agir.

\section{REFERÊNCIAS}

AMARAL JUNIOR, Alberto do. Introdução ao Direito Internacional Público. São Paulo: Atlas, 2008.

ARAÚJO, Nádia de; ANDREIUOLO, Inês da Matta. A Internalização dos Tratados no Brasil e os Direitos Humanos. In: BOUCAULT, Carlos Eduardo de Abreu; ARAÚJO, Nádia de (orgs.). Os Direitos Humanos e o Direito Internacional, Rio de Janeiro: Renovar, 1999, pp. 63-113.

\footnotetext{
${ }^{31}$ A natureza jurídica da sentença internacional decorre do status constitucional do tratado de direitos humanos que criou a Corte Interamericana de Direitos Humanos, ou seja, da natureza constitucional do Pacto de San José da Costa Rica.

${ }^{32}$ O STF já reconheceu que não cabe mais a prisão civil do depositário infiel acolhendo os termos do Pacto de San José da Costa Rica que a proíbe, apesar de o texto constitucional de 1988 prevê-la (Súmula Vinculante $n^{\circ} 25$, STF).

${ }_{33}$ LAFER, Celso. A Reconstrução dos Direitos Humanos: um diálogo com o pensamento de Hannah Arendt. São Paulo: Companhia das Letras, 1988.
} 
BARROSO, Luís Roberto. O Direito Constitucional e a Efetividade de suas Normas Limites e Possibilidades da Constituição Brasileira. 7. ed., Rio de Janeiro: Renovar, 2003.

BOBBIO, Norberto. A Era dos Direitos. Tradução de Carlos Nelson Coutinho. Nova ed., $7^{\mathrm{a}}$ reimpressão. Rio de Janeiro: Elsevier, 2004.

BOBBITT, Philip. A Guerra e a Paz na História Moderna: o impacto dos grandes conflitos e da política na formulação das nações. Tradução de Cristiana Serra, Rio de Janeiro: Campus, 2003.

CANÇADO TRINDADE, Antônio Augusto. A Proteção Internacional dos Direitos Humanos: Fundamentos Jurídicos e Instrumentais Básicos. São Paulo: Saraiva, 1991.

O Esgotamento dos Recursos Internos no Direito Internacional. Brasília: Editora UnB, 1984.

COMPARATO, Fábio Konder. A Afirmação Histórica dos Direitos Humanos. São Paulo: Saraiva, 1999.

DALLARI, Dalmo de Abreu. O Futuro do Estado. 2. ed., rev. e atual., São Paulo: Saraiva, 2007.

DOLINGER, Jacob. As Soluções da Suprema Corte Brasileira para os Conflitos entre o Direito Interno e o Direito Internacional: um exercício de ecletismo. Revista Forense: Rio de Janeiro, vol. 334, 1996, pp. 71-107.

FREITAS, Riva Sobrado de. Aspectos do Estado Contemporâneo e Desafios na Formulação das Políticas Sociais. Sequencia - Estudos Jurídicos e Políticos Revista do Curso de Pós-graduação em Direito da UFSC, ano XXVII, dez. 2008, p. 31-46.

LAFER, Celso. A Reconstrução dos Direitos Humanos: um diálogo com o pensamento de Hannah Arendt. São Paulo: Companhia das Letras, 1988.

MAEOKA, Erika. O Acesso à Justiça e a Proteção dos Direitos Humanos: os desafios à exigibilidade das sentenças da Corte Interamericana. Trabalho publicado nos Anais do XVII Congresso Nacional do CONPEDI, realizado em Brasília-DF, em nov. de 2008. MORAES, Alexandre de. Direito Constitucional. 15. ed., São Paulo: Editora Atlas, 2004.

PETIOT, Patrick. A Responsabilidade Internacional do Estado Brasileiro por Violação de Direito Humanos: o pagamento de reparações. Dissertação de Mestrado da UnB, 2005.

PIOVESAN, Flávia. Direitos Humanos e o Direito Constitucional Internacional. 7. ed., São Paulo: Saraiva, 2006.

Justiciabilidade dos Direitos Sociais e Econômicos: desafios e perspectivas. In: CANOTILHO, J.J. Gomes et al (coord.). Direitos Fundamentais Sociais, São Paulo: Saraiva, 2010, p. 53-69.

Palestra proferida no Seminário Internacional "O Tribunal Penal Internacional e a Constituição Brasileira", promovido pelo Centro de Estudos Judiciários do Conselho da Justiça Federal, no dia $1^{\circ}$ de outubro de 1999, no auditório do Superior Tribunal de Justiça, em Brasília - DF. Revista CEJ, Brasília, nº 11, p. 65-74, maio/ago., 2000.

RAMOS, André de Carvalho. Direitos Humanos em Juízo. São Paulo: Max Limonad, 2001. 
Processo Internacional de Direitos Humanos: análise dos sistemas de apuração de violações de direitos humanos e implementação das decisões no Brasil. Rio de Janeiro: Editora Renovar, 2002.

A Execução das Sentenças da Corte Interamericana de Direitos Humanos no Brasil. In: CASELLA, Paulo Borba et tal (org.). Direito Internacional, Humanismo e Globalidade: Guido Fernando Soares. São Paulo: Editora Atlas, 2008, p. 451-468.

. Crimes da Ditadura Militar: a ADPF 153 e a Corte Interamericana de Direitos Humanos. In: GOMES, Luiz Flávio; MAZZUOLI, Valério de Oliveira (org.). Crimes da Ditadura Militar: uma análise à luz da jurisprudência atual da Corte Interamericana de Direitos Humanos: Argentina, Brasil, Chile, Uruguai. São Paulo: Editora Revista dos Tribunais, 2011, p. 174-225.

SANT'ANA, Janice Cláudia Freire. O Brasil e a Execução de Sentença da Corte Interamericana de Direitos Humanos. In: ANNONI, Danielle (org.). Os Novos Conceitos do Novo Direito Internacional: Cidadania, Democracia e Direitos Humanos. Rio de Janeiro: América Jurídica, 2002.

TAIAR, Rogério. Direito Internacional dos Direitos Humanos: uma discussão sobre a relativização da soberania face à efetivação da proteção internacional dos direitos humanos. Tese de Doutorado, 2009. 